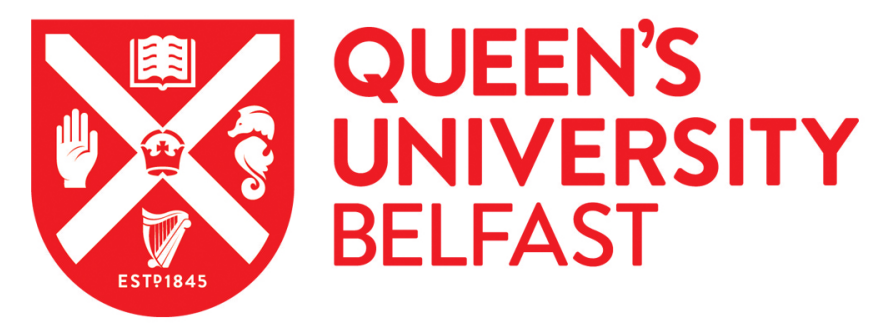

\title{
International Comparative Case Studies: Multiple Methods In Action
}

Penn, R. (2019). International Comparative Case Studies: Multiple Methods In Action. SAGE Research Methods: Cases, 1-14. https://doi.org/10.4135/9781526467041

\author{
Published in: \\ SAGE Research Methods: Cases
}

Document Version:

Publisher's PDF, also known as Version of record

Queen's University Belfast - Research Portal:

Link to publication record in Queen's University Belfast Research Portal

\footnotetext{
General rights

Copyright for the publications made accessible via the Queen's University Belfast Research Portal is retained by the author(s) and / or other copyright owners and it is a condition of accessing these publications that users recognise and abide by the legal requirements associated with these rights.

Take down policy

The Research Portal is Queen's institutional repository that provides access to Queen's research output. Every effort has been made to ensure that content in the Research Portal does not infringe any person's rights, or applicable UK laws. If you discover content in the Research Portal that you believe breaches copyright or violates any law, please contact openaccess@qub.ac.uk.
} 


\section{@SAGE researchmethods cases International Comparative Case Studies: Multiple Methods in Action}

Contributors: Roger Penn

Pub. Date: 2019

Access Date: January 3, 2019

Academic Level: Postgraduate

Publishing Company: SAGE Publications Ltd

City: London

Online ISBN: 9781526467041

DOI: http://dx.doi.org/10.4135/9781526467041

(C) 2019 SAGE Publications Ltd All Rights Reserved.

This PDF has been generated from SAGE Research Methods Cases. 


\section{Abstract}

This case sets out the multiple methods deployed in an international comparison of paper mills. The research involved a combination of research methods, including interviews, observations, focus groups, questionnaires, and secondary analysis. The six case studies were designed to probe existing theories concerning the relationship between technological change and skilled work and, in particular, the impact of computerization of paper manufacturing on the job skills of production and maintenance workers. The six case studies were located in Britain, Australia, and the United States, and in each plant, the same set of questions was asked, using the same combination of methods. The case outlines the complex issues surrounding access to the six mills. In particular, it focuses on the vital need to gain the agreement and confidence of both management and trade unions in order to conduct effective fieldwork. There proved to be very little existing research on the topic of paper mills in the social scientific literature. Rather, the case discusses the wide range of non-academic literature that provided useful insights into the global paper industry and the computerization of production that was underway at the time of the empirical research. The case reveals the close interplay of observation and interviews in the case studies. Both methods involve questioning the social world and were intertwined in practice throughout. The use of a semi-structured interview schedule and subsequently a more formalized questionnaire ensured that the questioning followed closely bounded parameters. The case also reveals how existing theories were modified as a result of the findings and applied in revised form in subsequent empirical research.

\section{Learning Outcomes}

By the end of this case, students should be able to

- Understand how to undertake a case study

- Grasp how to integrate a multiplicity of different research methods in a comparative case study

- Understand how observation and interviewing can be combined to produce an effective and rich explanation of social phenomena

- Understand how empirical research is both embedded within prior theoretical debates and can be used to develop new theoretical formulations

\section{Introduction}

This Case Study in Research Methods sets out the multiple methods used in an international comparison of paper mills in Britain, Australia, and the United States. The research involved the combination of a range of research methods including individual face-to-face interviews, observations in the field, focus groups, questionnaire design and implementation, and secondary analysis of relevant documents. It also involved the 
2019 SAGE Publications, Ltd

production of diagrams as hermeneutic devices. The case studies were designed to test existing theories as well as to contribute to the development of new theoretical explanations.

\section{The Context}

The immediate context for the development of the case study research analyzed in this Research Methods Case was my earlier research into skilled workers in the British class structure (see Penn, 1985a). This was driven by the disjunction between the discourse of sociologists and historians as to when an homogenous "working class" could be said to have existed in Britain and when it ceased to exist as a result of the division between skilled and nonskilled workers. In that research, I had examined economic differentials between skilled and nonskilled workers since the mid nineteenth century and also how skilled work had been reproduced through mechanisms of social exclusion. This had led me into the debate about technological change and skill in the contemporary workplace at the time. In particular, I read the seminal neo-Marxist work of Braverman (1975), which argued that there was a pervasive process of deskilling underway in the contemporary workplace as a result of the advent of computerization. However, his evidence for this thesis was poor and highly tendentious.

This debate about contemporary trends in skill prompted a series of empirical investigations into skilled work that coalesced into the Skilled Worker Project at Lancaster University. These pieces of research culminated in the publication of Class, Power and Technology (Penn, 1990a) and subsequently Skill and Occupational Change (Penn, 1994). The research included projects on the coal, metalworking, and telecommunications industries and also — centrally — the manufacture of paper which forms the basis for the present Case Study in Research Methods. Why did I undertake research into the paper industry? A major factor was its close proximity. Two mills were located within 10 miles of my home in Lancaster, and there were many other mills in the broader North West region of England.

\section{Case Studies}

The incorporation of case studies has been integral to the teaching of law and management within business schools for over a century. The use of case studies has also become a central method in the social and management sciences. They rose to prominence in the mid-20th century with the publication of seminal studies in the United States like Yankee City (Warner \& Lunt, 1941) and Middletown (Lynd \& Lynd, 1957). Subsequently, case studies became prominent in the development of economic sociology in Britain with the publication of the Affluent Worker series (Goldthorpe, Lockwood, Bechhofer, \& Platt, 1968a, 1968b, 1969) set in three factories in Luton and later within Gallie's (1978) In Search of the New Working Class, which was located in four oil refineries, two in Britain and two in France.

Case studies rely on both quantitative and qualitative evidence (see Yin, 2004, p. xv) and embody a set of multiple methods that can only be determined within the process of the actual empirical research itself (see 
2019 SAGE Publications, Ltd

George and Bennett, 2005). Case studies can involve single or multiple cases (Bartlett \& Vavrus, 2017; Yin, 2004). They can also involve comparisons within countries (which was the case in the Social Change and Economic Life Research Initiative in Britain in 1985) or comparisons across countries, as exemplified by Gallie (1978). As Hantrais and Mangen (1996) put it,

for the study to be cross-national and comparative, individuals or teams should set out to study particular issues or phenomena in two or more countries with the express intention of comparing their manifestations in different socio-cultural settings, using the same research instruments. (p. 1)

A case study is an "in-depth, multifaceted investigation conducted in great detail and relying upon a variety of data sources" (see Feagin, Orum, \& Sjoberg, 1991, p. 2). It involves an examination of social phenomena in detail and in context. Case studies allow the grounding of observations and concepts about social patterns within natural settings. They also permit and facilitate theoretical innovation and generalizations. Indeed, case studies are central to the development of what Glaser and Strauss (1967) termed "grounded theory" and involve a dialectical methodology where research questions and evidence interact and interplay in the comparison of rival abstract theories. They involve multiple styles of empirical research (see George and Bennett, 2005) and centre upon the "triangulation of results from different sources" (see Yin, 2014, p. 241).

Case studies can be used to examine and also to help generate new theories of how the social world is organized. Unlike the natural sciences, social scientists rarely conduct classic controlled experiments to test for the impact of one factor on a specific outcome. Rather, they probe the world as it is naturally constituted and structured and ascertain the impact of a variety of social factors upon specific outcomes in the social world.

\section{The Empirical Research}

The study of technological change and job skills in the paper industry had two phases. The first involved three case studies of local paper mills in England-James Cropper's of Burneside, Henry Cooke's in Beetham, and Thames Board in Workington (see Penn \& Scattergood, 1985). The focus was on changes in technology and job skills in the main production processes at the three mills. These were examined between 1970 and 1984. Such a recent historical time frame was manageable as respondents could—in the main —remember the production process at the earlier date and make informed comparisons between that earlier time and the contemporary era in 1984. The second phase of the research involved returning to all three of these original plants and probing technical change and job skills in greater detail and also extending the research to two paper mills in Australia and one in the United States (see Penn \& Scattergood, 1988). The Australian research conducted in the autumn of 1984 was funded by a grant from the Australian Studies Centre and the American research took place during a sabbatical at UC Berkeley in the spring of 1985. This was supported by a grant from the Lancaster University Research Fund to assist research on skilled workers in the United States. In each of the six case studies, the same set of questions was asked, using the same array of methods.

The two phases of the research were designed to probe the competing theories about the putative effects of 
2019 SAGE Publications, Ltd

technological change on job skills. These were grounded in the sociological literature at the time and could be seen as mutually exclusive. The first was the "deskilling" thesis associated with Braverman and, more widely, with neo-Marxism. This argued that technical change produced decreasing levels of skill over time. The counter-theory was the "skilling" thesis associated with post-industrialism and human capital theory which posited a general increase in levels of skill associated with technical change in the twentieth century. Much of this debate revolved around the putative effects of computerization which was growing rapidly in workplaces during the 1980s.

\section{Access}

It was essential to gain access to the plants that formed the cornerstone of the empirical research. In the first phase of the research in Britain, letters were sent initially to the managing directors of the three firms. These were sent by post on university-headed paper and outlined the basic parameters of the proposed research and sought a meeting to discuss the research more fully. These proved successful and the research team undertook preliminary interviews and observations of the production process at each of the three plants. Each mill produced a different product. Cropper's manufactured colored paper and card, Thames Board produced glossy carton board that ended up in the outer packaging of cereal and soap powder boxes and Henry Cooke's made specialty papers used in the packaging of frozen foods.

Each of the three plants was unionized. Indeed, at each factory, there was more than one trade union represented. The cooperation of these unions was also sought as we proposed to observe and also interview the workforce. Without the cooperation of the unions, the research would have not been possible. Each union was contacted by letter. In the case of the Amalgamated Engineering Union (AEU), the letter was sent to their District Secretary in Barrow and his agreement received by letter. In the cases of the Electricians' Union (Electrical, Electronic, Telecommunications and Plumbing Union [EEPTU]) and the Paperworkers' Union (Society of Graphical and Allied Trades [SOGAT]), it proved necessary to visit their respective headquarters to gain their approval. This was achieved successfully in each case, but the process took several months. Without this approval it would have proved impossible to conduct the fieldwork as we were constantly asked by the workforce if their union had agreed to our research.

Similar methods were used to gain access to the two paper mills researched in Australia. Letters were sent to the managing directors at Australian Paper Mills (APM) in Botany Bay and Australian Newsprint Mills (ANM) in Albury. The letters outlined the proposed comparative research and included a copy of the earlier U.K.based research for their information. The relevant trade unions were also contacted and a series of meetings with them organized. After positive responses from all parties, fieldwork was undertaken in the autumn of 1984. Access to the James River plant in Halsey Oregon was facilitated by Professor Sally Hacker from the Sociology Department at Oregon State University. She contacted the plant prior to my visit to Corvallis and enclosed a copy of the U.K. research report to provide the context for the U.S. stage of the proposed comparative research. 
2019 SAGE Publications, Ltd

\section{Literature Review}

A central part of any research project involves a literature review of pertinent previous work (see Fink, 2013; Ridley, 2008 for the best texts on how to undertake an effective literature review). However, there was very little literature directly pertinent to the paper industry itself: most literature dealt with the more general issues of technical change and the division of labour. A wide range of specialist industry publications were consulted. These included National Economic Development Office Reports as well as the monthly trade journal Paper and the annual Paper: Review of the Year. Documents were collected from the companies researched (including annual reports to shareholders) and from the various trade unions, including the National Graphical Association's "The Way Forward" as well as a copy of the agreement on "Programmable Logic Controllers" at APM in Botany Bay. I also attended an industry-based conference on automation which led to the publication of my presentation in the specialist journal Automation in 1985.

\section{Observation}

A core method of the research involved observation of production processes in the six paper mills. These were combined with interviews or, more precisely, detailed context-specific intensive questioning of what was being observed. A paper mill is a very large physical environment with enormous machines manufacturing paper and board. One area of production was a great puzzle initially, and this involved the mixing of dyes to produce colored paper and board at Cropper's. The skilled workers in this crucial area of the plant were called beatermen (they were all men). Computers had been added to the working environment over recent years, but it took the research team a long time to understand this process. This was partly because these skilled workers were not keen to divulge too much initially about the recipes that they used to achieve a color match. Halle (1987) described similar reticence among chemical worker in his study America's Working Man. The other factor in our puzzlement was our initial failure to grasp the distinction between computerized monitoring and computerized control of production processes. Computerized control involves computers automatically adjusting the production process as a result of information received from sensors embedded within the machinery itself. None of the six mills had such systems. Rather, they employed computerized monitoring systems. These provided information for skilled production workers on how the production process was functioning but-critically-these same workers were required to decide which adjustments to make themselves. In the case of color blending, the new computerized system provided information on whether the color mix was more or less the same as the template color desired. However, it did not provide any guidance on what to do when there was a mismatch. The research team discovered that dyes could vary in color: one barrel of vermillion could well be different from another. We also discovered that different batches of pulp would react differently to the same dyes. Finally, it became clear (albeit belatedly) that each beaterman had a different idea on which combination of dyes should be added to generate a change in the mix. This information had been hard won by the research team and the result of extensive engagement with these specialist skilled workers that had involved both detailed observations and prolonged questioning over a succession of visits in the field. 
2019 SAGE Publications, Ltd

\section{Interviews}

The other central method used in the six case studies of paper mills in Britain, Australia, and the United States was interviewing (the best current guide to interviewing remains Arksey \& Knight, 1999). These ranged in form. The initial phase of each of the six case studies entailed open-ended, unstructured interviews with senior managers and trade union officials in order to secure access for the subsequent fieldwork. These always took place at their places of work, and it was important to dress appropriately for these preliminary interviews which, at that time, meant a suit or a jacket and tie. The interviews were open-ended and designed to explain the nature of the proposed research. Clearly, being a university academic helped in all cases and the first report on the British phase of the research assisted in obtaining access to the Australian and American plants.

Subsequent interviews were also open-ended and lasted between 40 and 180 min. However, they were semi-structured and based upon a set of questions that had been formulated by the research team, but these interviews were also free flowing and covered many other topics as well. The interviews were recorded and notes taken during them as well. This was part of the wider process of understanding the language of descriptions used within the industry. The schedule meant that each interview produced a set of answers that could be compared across cases and, by extension, across countries.

\section{Focus Groups}

The research used two focus groups to probe the issues surrounding technical change and the division of labour in greater depth (see Kreuger \& Casey, 2014; Morgan \& Kreuger, 1997 for the best guides to focus groups). Focus groups have many advantages. They are particularly useful for probing group attitudes, feelings, and beliefs. Both focus groups were hybrid in the sense that the two groups had been organized by management at Cropper's and Thames Board respectively. The first, at Cropper's involved a group of 10 production workers who were attending a course in the company's training suite and lasted $2 \mathrm{hr}$. The research team was invited to sit in and observe this meeting, and then, we were allowed to participate in the group discussion and ask our own questions. Notes were taken during these discussions and typed up immediately afterwards. The second involved a group of 16 employees at Thames Board and lasted from 9.30 am to $4 \mathrm{pm}$. The central aim of the meeting was to introduce the workforce to a new style of management and working called "Total Quality Management." The team was invited to participate in this meeting, and once again extensive notes were taken.

Both hybrid focus groups provided insights into the everyday language of descriptions prevalent within the two firms. The central advantage of these focus groups was that it helped the research team understand the issues of technical change and job skills within the paper industry as perceived by the workforce itself. They also provided an insight into the everyday language used to discuss these topics. Indeed, it provided a route into the wider language of the organization. Every organization has a set of codes to describe that organization which can prove obscure to outsiders. In my own work, I had encountered this in several 
2019 SAGE Publications, Ltd

pieces of research I had conducted. The first involved participant observation among telephone maintenance technicians (see Penn, 1991b). The language that they used to describe British Telecom and their jobs was opaque to put it mildly. Part of any successful fieldwork involves the researcher "learning the language of descriptions" (see Garfinkel, 1967). I experienced very similar issues when I researched the changing skills of coal miners (see Penn \& Simpson, 1986). I spent a great deal of time in discussions with miners about the occupational system at the time of the research as well as in previous periods. This proved extremely complicated to achieve.

These two hybrid focus groups raised a wide range of issues that were probed in more detail subsequently by the research. Of particular interest were the debates between members of the workforce over issues of skill and demarcation. Clearly, there was considerable anxiety surrounding both technical change and new styles of management as well as fear concerning the putative effects of computerization on working practices and job skills.

\section{Questioning the Social World: The Interplay of Observation and Interviews}

The two core methods used in these six case studies involved observation and interviews. However, the two methods were closely entwined in practice. When observing the production process in a paper mill, a series of questions arose that were posed to the workforce. This was somewhat intrusive, but generally, the research team discovered that most of the workforce was more than happy to discuss what was going on. At the beginning, our questions were overly general and rather abstract, but as we learned the linguistic codes used within the industry and also the language used to describe the occupational system, our questions became much more specific. The research involved a continuous questioning of participants in the workplace and an interplay between observations and interviews. This was particularly evident in Australia and the United States. Indeed, Professor Sally Hacker who accompanied me on my visit to the paper mill in Halsey, Oregon, was kind enough to recognize this subsequently at the annual meeting of the American Sociological Association in Chicago in 1987 when she spoke about how the workforce had reacted positively to my detailed questions. Gaining such proficiency, knowledge, and confidence took time. It is an iterative process that can only be learned in the field through the actual process of detailed questioning itself. It very much involves trial and error. This dialectical learning process led directly to the discovery of a range of key conceptual findings that became integral to the Skilled Worker Project and to wider debates in economic sociology.

The first involved the critical distinction between production and maintenance skills. The effects of computerization on these two areas of work were distinctive and should not be elided. In general terms, computerization of production processes generates more skilled maintenance workers and fewer skilled production workers. Clearly, some occupational groups gain numerically while others do not. If the two groups are conflated and combined, then the overall effect will be zero! This central finding rendered the traditional 
2019 SAGE Publications, Ltd

focus of industrial sociology exclusively on production workers obsolete and potentially highly misleading. Given that production workers in paper mills are generally organized in separate trade unions to maintenance workers, technical change will also impact asymmetrically on industrial relations within plants. This was evident across all six case studies in the three countries.

The second important discovery made as a result of the interplay of observation and interviews involved the two trajectories into skilled work evident in all six mills. Maintenance workers such as electricians and fitters had all undergone traditional apprenticeships lasting at least three years in their late teens. This formed the core basis for their skilled status. Skilled production workers such as machinemen and beatermen experienced a very different path into skilled work. They progressed along an internal career ladder that culminated in their skilled status and pay. This could take between 10 and 20 years to achieve and was identical in all three countries. This discovery led to the realization that many other industries had a similar bifurcated structure to skilled work. These included steel, coal, and textiles. This insight transformed the debate about skilled workers away from a narrow focus on apprenticed workers (see Penn, 1994). These differing trajectories of skilled work were central to the internal discourse about skill and relative pay within these paper mills. Skilled maintenance workers with apprenticeship qualifications were reluctant to accept the claims of skilled production workers to an equivalent "skill" in all six mills.

The interplay of observation and interviews was also evident in the development of our understanding of the technologies that had been implemented in each of the mills. This took some time as the team did not know a great deal initially about these details. Fortunately, only a small number of firms manufacture papermaking machinery and even fewer provide the computer systems that are bolted onto these machines. Once again, the interplay of observation and interviews led the team to develop an expertise in these areas that facilitated a deepening of the overall research. We discovered that not only were maintenance skills increasing in terms of the numbers of skilled maintenance workers employed over time but that there was an asymmetry in these developments. There had been an increasing premium on electronic skills but less in terms of mechanical skills. This affected electricians and mechanics directly and had led to a range of similar demarcation disputes in the three countries. These had occurred irrespective of whether the skilled trades were in separate or the same trade unions. Once again the deep-seated, taken-for-granted assumptions of industrial sociology were challenged by these empirical findings: none of which would have been possible without the combination of observation and interviews.

The final important discovery was the intermittent use of skill. Much of the time skilled production and skilled maintenance workers would be scanning the large number of computer monitors which provided continuous information about the ongoing manufacturing processes. In some respects, it might have appeared as if they were doing very little, but in fact, they were assessing how the machinery was functioning. Only when problems began to emerge did the various skilled workers jump into action. Given the intermittent nature of these episodes, considerable time in the field was necessary to capture and interpret these phenomena.

\section{Questionnaires}


2019 SAGE Publications, Ltd

The research also made some use of questionnaires in its second phase. These questionnaires were formalized versions of the initial schedule of questions used during the semi-structured interviews in the first phase. In both instances, the main aim was to ensure that the same sets of questions were asked at each of the six plants and the same information collected in order to facilitate comparisons across the case studies. Such a structure to questioning in comparative case study research is an essential part of organizing such research and serves to make the data collection manageable.

\section{Diagrams}

The research team created a diagram titled "The Production of Paper" (see Penn \& Scattergood, 1985, p. 627 ) as a heuristic device to represent the production process in a paper mill in a simplified form and to complement the written analyses. In particular, the diagram provided a visual guide to the location of the various occupations within the overall production process. Nowadays, it would probably prove possible to take photographs of the production process and the various types of work associated with papermaking, but the diagram would still provide a useful guide to the phenomena analyzed in the six case studies (Figure 1).

Figure 1. The production of paper.

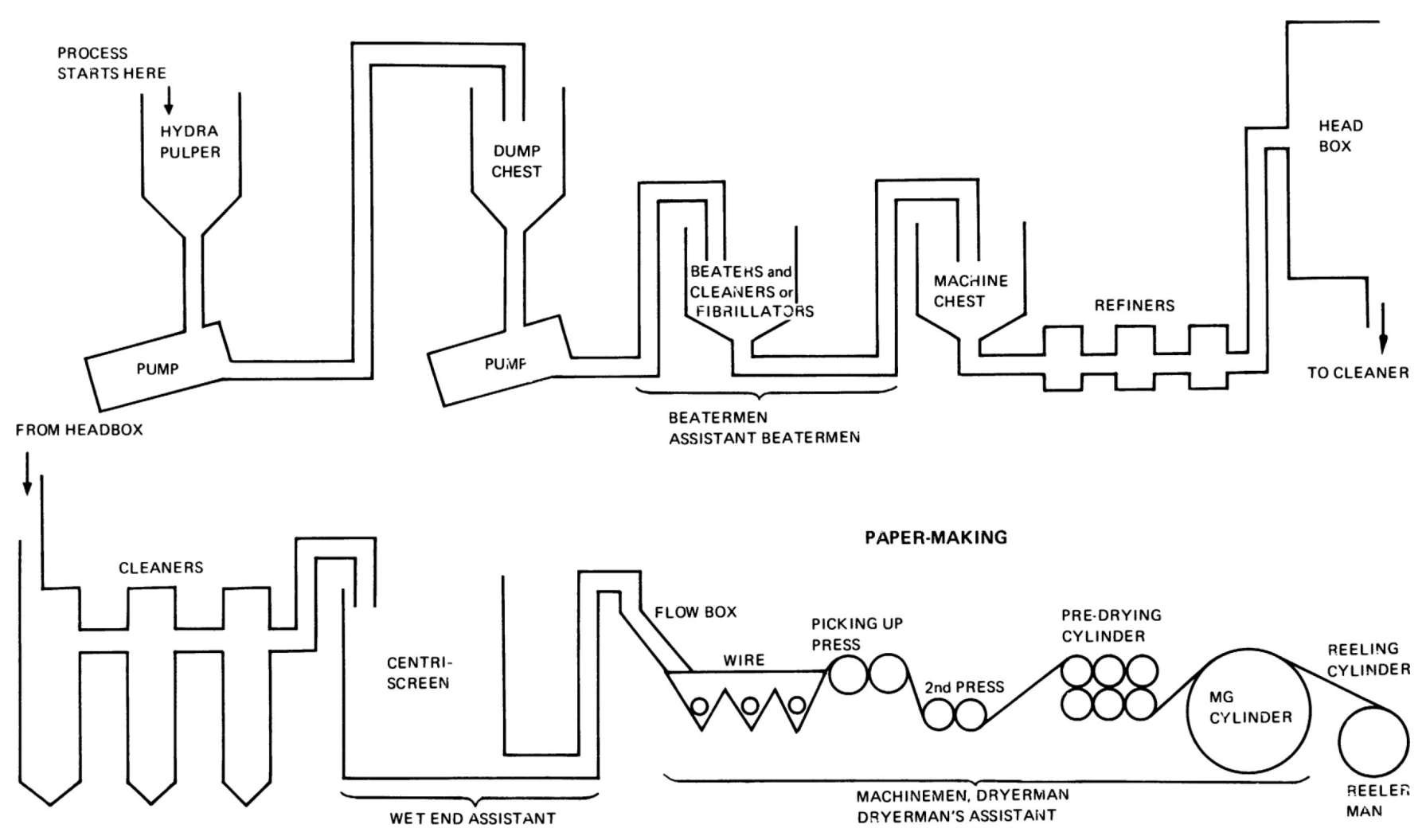

\section{Theoretical Developments}

The case studies were designed to probe the competing theories of the relationship between technical change and the division of labour within the broader sociological literature. The compensatory theory of 
2019 SAGE Publications, Ltd

skill had been devised during the early phases of the British fieldwork and was probed extensively in the two published analyses. The compensatory theory of skill suggested that "technical change generates both skilling and deskilling" (Penn \& Scattergood, 1985, p. 615) and that "technological changes tend to deskill direct production roles but put an increased premium on a range of ancillary tasks that are associated with the installation, maintenance and programming of automated machinery" (Penn \& Scattergood, 1985, p. 616). The case studies probed this theory in detail and concluded that "technical change did generate positive effects on skill but not much in the way of deskilling" (Penn \& Scattergood, 1985, p. 625). As a result of these findings, the compensatory theory of skill was modified for subsequent research and extended to include clerical and secretarial workers as well (see Penn, 1994). The development of theory progresses best with the interplay of empirical research findings and conceptual reformulations.

\section{Practical Lessons Learned}

The main lessons of this case study involved the importance of integrating a wide range of different research methods and techniques for the successful implementation of comparative case study research. The central methods involved interviews and observations. These were supplemented with questionnaires and secondary research as well as literature searches. In each of the six case studies, the same set of questions was asked, deploying the same combination of methods. The data collected from observations and interviews were triangulated to develop the overall interpretation. Indeed, the two core methods were intertwined within the fieldwork itself. The research process was iterative and cumulative. A central feature of the research involved translating the industrial and occupational language used routinely within the paper industry globally into a more general language of descriptions suitable for non-specialists and more generally for use within economic sociology.

\section{Exercises and Discussion Questions}

1. How important are observations for understanding how workplaces function?

2. How can researchers learn the "language of descriptions" within a case study of a specific organization?

3. What sort of visual data could be integrated into a comparative case study like the one analyzed? How would it improve the analysis?

4. How could extending the comparative research outlined in this case to countries where English is not the first language be developed?

\section{Further Reading}

Arksey, H., \& Knight, P. (1999). Interviewing for social scientists: An introductory resource with examples. London, England: SAGE. 
2019 SAGE Publications, Ltd

Bryne, D., \& Ragin, D. (Eds.). (2013). The SAGE handbook of case-based methods. London, England: SAGE.

Hantrais, L., \& Mangen, S. (Eds.). (1996). Cross-national research methods in the social sciences. London, England: Pinter.

Yin, R. (2014). Case study research: Design and methods (5th ed.). London, England: SAGE.

\section{References}

Bartlett, L., \& Vavrus, F. (2017). Comparative case studies: An innovative approach. Nordic Journal of Comparative and International Education, 1, 5-17.

Belfiore, E. (2004). The methodological challenge of cross-national research: Comparing cultural policy in Britain and Italy (Research Paper No. 8). Coventry, UK: Centre for Cultural Policy Studies, University of Warwick.

Bryne, D., \& Ragin, D. (Eds.). (2013). The SAGE handbook of case-based methods. London, England: SAGE.

Eisenhardt, K. (1989). Building theories from case study research. The Academy of Management Review, $14,532-550$.

Feagin, J., Orum, A., \& Sjoberg, G. (1991). The case for the case study. Chapel Hill: University of North Carolina Press.

Gallie, D. (1978). In search of the new working class: Automation and social integration within the capitalist enterprise. Cambridge, UK: Cambridge University Press.

Garfinkel, H. (1967). Studies in ethnomethodology. New York, NY: Prentice Hall.

George, A., \& Bennett, A. (2005). Case studies and theory development in the social sciences. Cambridge, MA: MIT Press.

Glaser, B., \& Strauss, A. (1967). The discovery of grounded theory. Chicago, IL: Aldine.

Goldthorpe, J., Lockwood, D., Bechhofer, F., \& Platt, J. (1968a). The affluent worker: Industrial attitudes and behaviour. Cambridge, UK: Cambridge University Press.

Goldthorpe, J., Lockwood, D., Bechhofer, F., \& Platt, J. (1968b). The affluent worker: Political attitudes and behaviour. Cambridge, UK: Cambridge University Press.

Goldthorpe, J., Lockwood, D., Bechhofer, F., \& Platt, J. (1969). The affluent worker in the class structure. 
2019 SAGE Publications, Ltd

Cambridge, UK: Cambridge University Press.

Halle, D. (1987). America's working man: Work, home and politics. Chicago, IL: Chicago University Press.

Hancock, D., \& Algozzine, B. (2011). Doing case study research: A practical guide for beginning research. New York, NY: Teachers' College Press.

Hantrais, L., \& Mangen, S. (Eds.). (1996). Cross-national research methods in the social sciences. London, England: Pinter.

Hooks, G. (1990). The rise of the Pentagon and US State building: The defense program as industrial policy. American Journal of Sociology, 96, 358-404.

Klonowski, R. (2013). The case for case studies: Deriving theory from evidence. Journal of Business Case Studies, 9, 261-266.

Kreuger, R., \& Casey, M. (2014). Focus groups: A practical guide for applied research (5th ed.) London, England: SAGE.

Lynd, R., \& Lynd, H. (1957). Middletown: A case study of modern American culture. Orlando, FL: Harcourt Brace.

Morgan, D., \& Kreuger, R. (1997). The focus group kit (Vols. 1-6). London, England: SAGE.

Penn, R. (1985a). Skilled workers in the class structure. Cambridge, UK: Cambridge University Press.

Penn, R. (1985b). Skilled workers and automation in contemporary Britain. Automation, pp. 8-9.

Penn, R. (1990a). Class, power and technology: Skilled workers in Britain and America. Cambridge, UK: Polity Press.

Penn, R. (1990b). Skilled maintenance work at British Telecom. New Technology, Work and Employment, 5, $135-144$.

Penn, R. (Ed.). (1994). Skill and occupational change. Oxford, UK: Oxford University Press.

Penn, R., Lilja, K., \& Scattergood, H. (1992). Flexibility and employment patterns in the contemporary paper industry. Industrial Relations Journal, 23, 214-223.

Penn, R., \& Scattergood, H. (1985). Deskilling or enskilling? An empirical investigation of the labour process. British Journal of Sociology, 36, 611-630.

Penn, R., \& Scattergood, H. (1988). Continuities and change in skilled work: A comparison of five manufacturing plants in the UK, Australia and the USA. British Journal of Sociology, 39, 69-85. 
2019 SAGE Publications, Ltd

Penn, R., \& Simpson, R. (1986). The development of skilled work in the British coal mining industry, 1870-1985. Industrial Relations Journal, 17, 339-349.

Ragin, C., \& Zaret, D. (1983). Theory and method in comparative research: Two strategies. Social Forces, $61,731-754$.

Roig-Tierno, N., Gonzalez-Cruz, F., \& Llopis-Martinez, J. (2017). An overview of qualitative comparative analysis. Journal of Innovation \& Knowledge, 2, 15-23.

Rowley, J. (2002). Using case studies in research. Management Research News, 25, $16-27$.

Scholz, R., \& Tietje, O. (2001). Embedded case study methods: Integrating quantitative and qualitative knowledge. London, England: SAGE.

Warner, W., \& Lunt, P. (1941). Yankee City: The social life of a modern community. New Haven, CT: Yale University Press.

Whyte, W. (1943). Street corner society: The social structure of an Italian slum. Chicago, IL: University of Chicago Press.

Yin, R. (2014). Case study research: Design and methods (5th ed.). London, England: SAGE. 